José María Yebra*

\title{
Transmodern Motion or the Rhizomatic Updated in In a Strange Room, "Take me to Church" and Babel
}

https://doi.org/10.1515/ang-2018-0050

Abstract: The article aims at exploring how the concept of the transmodern fits, comprises and helps to understand transcultural events from a wider perspective. To do so, three metaphors will be addressed, namely Enrique Dussel's 'jungle', Gilles Deleuze’s and Félix Guattari’s ‘rhizome’ and Sarah Dillon’s ‘palimpsestuous palimpsest'. In all three cases, issues like multiplicity, connectedness and a sense of motility are present. And, the article proves, they prove valid to render the aesthetic, ethical and political possibilities of contemporary texts that range from literature, Damon Galgut's In a Strange Room (2010), to music, Hozier's hit "Take me to Church” (2014), and to cinema, González Iñárritu's Babel (2006). ${ }^{1}$

\section{Transmodernism(s) and its Metaphors of Connectedness}

Transculturalism, Maurizio Ascari points out, "goes beyond intercultural and multicultural perspectives in the deconstruction of the $18^{\text {th }}$-century concept of single cultures, proving both more descriptively attuned to present reality and projectually more open” (2011: 6). In opposition to interculturalism and multiculturalism, which "fail to challenge the traditional view of cultures as 'spheres' or 'islands”' (Ascari 2011: 6), transculturalism focuses on the differences that make cultural similarities meaningful. According to Irene Nordin, Julie Hansen and Carmen Zamorano, it "fosters an inclusive, rather than an exclusive, understand-

1 The research carried out for writing this article is part of a project financed by the Spanish Ministry of Economy and Competitiveness (MINECO) (code FFI2015-65775-P). The author is also grateful for the support of the Government of Aragón and the European Social Fund (ESF) (code H05).

*Corresponding author: José María Yebra, Universidad de Zaragoza

E-Mail: jyebra@unizar.es 
ing of culture as characterised by differences; it emphasises the need for groups to identify common ground among cultures, and the need for the individual to acknowledge the foreign within oneself in order to be able to comprehend the others" (2013: x). A renewed sense of relationality is hence favoured; one that rejects the Other's difference as reductible, but assumes it is a transcultural meeting point. Despite disapproving voices, transculturalism seems to constitute the sign of the present, for it bears witness to a number of current phenomena. In particular, this article will focus on 'transness' as a metonymy for transmodernity and globality. I contend that transmodernity is the paradigm whereas transculturality and globalisation are the symptoms of its motility and planetarist vocation. “'Trans' is everywhere: in language [translation]; in politics and geography [transnational, transcontinental, transposition]; in metaphysics [transcendental or not]; in movement [transportation, transmission, transversal]; in gender [transgender]; and real change [transmogrify, transform]" (Stimpson 2016: n. pag.). I take 'transness' as a compelling concept, or rather a meeting process, relational and worldwide, though born in the West. It is 'essentially' motile, and thus linked to mobility studies, migration and nomadism via Said's travelling theory. 'Transness' is both centripetal and centrifugal because a point of connectiveness is established only to be left behind in "lines of flight", using Deleuze and Guattari's terminology (2015: 9). In practical terms, critics like Ascari (2011), Nordin, Hansen and Zamorano (2013) and Dagnino (2015) give many examples of the new paradigm of globalised voices in the move: Magda Szabó, Haruki Murakami, Jonathan Safran Foer, Azar Nafisi, Lara Vapnyar, Chris Cleave, Monica Ali, Assia Djebar, Inez Baranay, Brian Castro, Tim Parks and Ilija Trovanow among others. Studies so far have focused exclusively on fiction. This article, however, addresses fiction as well as cinema and music since texts, no matter their format, increasingly respond to 'transness'. Novels like Damon Galgut's In a Strange Room (2010), David Mitchell's Ghostwritten (1999) and Cloud Atlas (2004), Mohsin Hamid's The Reluctant Fundamentalist (2007), films like Babel (2006) by Alejandro González Iñárritu and Terrence Malick's The Tree of Life (2011) and music videos like Hozier's “Take me to Church" (2014) are but a few examples. All of them traverse time and (especially) socio-cultural space, making their discourses and/or characters' experiences coalesce beyond classic parameters well into what critics like Ghisi and Ascari call a planetary culture, which supersedes postmodernity and its postcolonial side-effect (Ascari 2011: 7-11). It is in this sense that transculturalism and transnationalism can be included in transmodernism, the term that Spanish philosopher Rosa Rodríguez Magda coined in 1989. It is my main contention that new transmodern 'texts' are motile responses to new 'realities' I will address making reference to the metaphors of Dussel's 'jungle', Deleuze and Guattari's 'rhizome' and, to a lesser extent, Dillon's reappraisal of Thomas De Quincey's palimpsest. 
Closely connected to Jameson's 'late-capitalism', Bauman's 'liquid modernity', Beck's 'second modernity' and Lipovetsky's 'hypermodernity', transmodernism focuses on 'trans' as transformation and transcendence, and especially on globalisation as the new paradigm that excludes and replaces former hegemonic systems (Rodríguez Magda 2013: 10). Contrary to modern (and postmodern) universalism, Magda opts for a 'situatedness' that configures one's standpoint without falling, however, in cultural relativism. No matter how transgressive transmodernism may be, the philosopher seems to eventually fall prey to her own arguments. She suggests that the interconnectedness of globalisation, the new Grand Narrative, is totalising (Rodríguez Magda 2013: 17), rather than effectively transgressive. Back to the conception of space, Magda's 'simultaneity', whereby territories are replaced by cyberspace and the global and the local merge into the glocal (Rovertson 1995), is essentially transmodern. She reifies glocalisation as a hybrid, transcending what she calls the premodern identity politics of postcolonialism (Rodríguez Magda 2013: 19). Rejecting the premodern is perhaps too radical or even unfair because, as Dussel (2002: 232-237) argues, premodern cultures have much to offer to the transmodern. Moreover, in the collection edited by Magda herself, Carles Lainez claims for a return of the premodern for the transmodern to succeed (2013: 169). Finally, although Magda aptly questions Eurocentrism, especially the poetics and the very concept of 'the Other' as well as the right to speak for that 'Other', she concludes that transmodernity is a dialectical synthesis of the modern thesis and the postmodern antithesis (Rodríguez Magda 2013: 19). It is paradoxical that she embraces the Hegelian dialectical method to frame a paradigm shift.

Transmodernism has later been addressed by critics such as Enrique Dussel (1996, 2001, 2002), Marc L. Ghisi (1999, 2008), Ziauddin Sardar (2004) and Jeremy Rifkin (2005, 2009). All of them assume a more hopeful stand than Magda, one closer to Rosi Braidotti's nomadism (2011):2 Dussel reclaims a transmodern transformation, no longer Eurocentric, allowing premodern cultures suppressed by Western modernity to arise. Sardar claims for the replacement of a homogenising globalisation with trans-relationality between the West and the Muslims. Ghisi's more theoretico-philosophical and political view has moved from intercultural dialogue to planetarist positions. Likewise, Rifkin turns to global empathy as essentially human and hence the motor of a paradigm shift, though from a more

2 Nomadism can be regarded as a complex event that comprises but transcends migration (literature). It is physical and 'meta-physical', nodal like the palimpsest and the rhizome, and motile like the latter. Yet, this motility does not necessarily imply physical movement, as Hozier's hit proves. It implies a change of status or a state of interconnected 'transness'. 
utopian outlook. It is the aim of this article to delve into "Take me to Church", In a Strange Room and Babel as examples of the transmodern paradigm shift.

The texts above long for a primordial stage, an iconography and values prior, or rather, contrary to the logic of Western modernity. Indeed, only a proper encounter with the premodern will allow the transmodern to unfold. It is no secret, as Riane Eisler argues, that premodernity should not be idealised either (1988: xiv). Although Eisler's partnership model prevailed in pre-Christian cultures (in contrast to the modern domination model), they also relied on "violence and injustice" (1988: xiv). In any case, the premodern or a-modern still constitute a reservation worth considering. In this light, I will firstly address Dussel's 'jungle' metaphor to approach the cultural complexity new texts convey. Also, Sardar's reappraisal of premodernity will be taken up to better understand the empathy poetics that informs an increasing number of texts and cultural events. Indeed, transmodern texts confer the metaphors signalled above both a political and ethical dimension.

Arguing for a return to premodern (non-Western) culture(s) to recover the human within the human and its essential relationality with the Other (understanding the Other in a wide trans-human sense), Dussel points out:

Like the tropical jungles with their immense quantity of plants and animals genetically essential for the future of humanity, the majority of humanity's cultures excluded by modernity [...] and by globalization [...] retains an immense capacity for and reserve of cultural invention essential for humanity's survival. This creativity will also be needed if humanity is to redefine its relationship with nature based on ecology and interhuman solidarity, instead of reductively defining it on the solipsistic and schizoid criterion of increasing rates of profit. (2002: 234-235)

Dussel's metaphor draws on Deleuze and Guattari's rhizome to meet Rifkin's translation from egology to ecology. Dussel's 'jungle', which returns to nature as a metaphoric and actual solution for current human deterritorialisation, ${ }^{3}$ is (like Deleuze and Guattari's 'rhizome' and Dillon's 'palimpsestuousness') planar and transespecies. Unlike arboreal/palimpsestic verticality, this model/habitat rejects hierarchy and a chronological dimension, being instead relational, interconnect-

3 Deterritorialisation has changed since it was firstly coined by Deleuze and Guattari in AntiOedipus (1972), even though most of the current undertones were present in the original concept. Apart from the schizoid and fluid nature of human subjectivity as derived from (late) capitalism, new deterritorialisations address human relation with the non-human, environmental issues, the effect of new technologies and migrations and nomadism. None of these points (except for the engrossed reality new technologies make up) is completely new. It is, however, their intensity that has increased. 
ed/ing and 'trans'. Whereas Deleuze and Guattari regard the rhizome as a mode of knowledge, I contend that this new scenario, which blends the rhizomatic (and the palimpsestuous) as metaphors of the 'jungle', does not follow the rules of classic knowledge; i.e. as knowing/mastering the Other. Instead, Dussel's 'jungle' reveals itself as the transition tool from egology (knowing) to ecology (sharing), as the connecting point between human and nature, the premodern and the transmodern. In short, it is the fishing ground of a humanness and relationality with the Other - be it nature or other humans - that needs upholding.

In relating Dussel's 'jungle' with the rhizome, the former becomes textual and the latter gains ecological credence. In fact, Deleuze and Guattari firstly approach the rhizome as a book, i.e. an assemblage of strata that "make it a kind of organism" (2015: 4). As a meeting-point of "multiplicities, lines, strata and segmentarities, lines of flight and intensities" (Deleuze and Guattari 2015: 4), it is 'essentially' relational. It exists "only through the outside and on the outside" (Deleuze and Guattari 2015: 4). The rhizome relies on the complexity of nature and more concretely on a number of principles, namely of connection and heterogeneity (Deleuze and Guattari 2015: 7), of multiplicity (Deleuze and Guattari 2015: 8), of cartography and decalcomania (Deleuze and Guattari 2015: 12). It is not unlike the palimpsestuous marks emerging on (and co-habiting with) current texts (Dillon 2005: 245) that the biosphere in the jungle supplies life and the rhizome a model for transmodern interconnectedness. The economy of the palimpsest - the original and new messages being written on the same leaf and related in "multi-linearity, nodes, links and networks" ("Palimpsest": par. 7) draws on the ecologic and relational economy the jungle addresses as actual ecosystem and metaphor. The palimpsestuous is bidimensional: the leaf and its text being haunted by and cohabiting with prior texts that keep re-surfacing. Drawing on Thomas De Quincey, Dillon regards the palimpsestuous palimpsest as "an involuted phenomenon where otherwise unrelated texts are involved and entangled, intricately interwoven, interrupting and inhabiting each other" (2005: 245). The rhizome extends the possibilities of the palimpsest, being acentered and polydimensional (Deleuze and Guattari 2015: 17). It thus breaks up with the tree, not as a living being, but as a concept: "We're tired of trees" Deleuze and Guattari point out (2015: 15). "We should stop believing in trees, roots and radicles. They've made us suffer too much. All of arborescent culture is founded on them, from biology to linguistic" (2015: 15). It is not that both critics are arguing against ecology. On the contrary, they are releasing the tree from the hierarchical discourse it has been inscribed into. The Book of Genesis stole the tree from nature making it a symbol of territorialisation, univocity, fixity and genealogy. Deleuze and Guattari claim for the rhizome to replace arborescence, not the living being. Unlike the arborescent, the rhizomatic terminates with ends and beginnings and 
aims instead at the middle in the form of 'becomings' (Deleuze and Guattari 2015: 21). Indeed, the rhizome "is made of plateaus", or middle areas, which designate "any multiplicity connected to other multiplicities by superficial underground stems" and which "communicate with each other across microfissures" (Deleuze and Guattari 2015: 22). This is the way transmodern texts work in my view. They are (made up of) plateaus or regions of intensity, which are interconnected, as we will see, through such microfissures.

Dussel's rhizomatic 'jungle' can be related to Sardar's complex systems, “societies, civilisations, eco-systems" (2004: n. pag.), which palimpsestuously cohabit with Western 'texts'. I am particularly concerned with the way these systems interact to make up new paradigms, transmodernism being one of them. Sardar's conception of transmodernism proves to be particularly illuminating, as it updates Dussel's. Dussel argues for a return to the premodern, ${ }^{4}$ the cultural 'ecosystem' that Eurocentric modernity has unsuccessfully tried to suppress. It is with the help of these premodern non-Western scenarios - closer to ecological positions than to a solipsistic and profit-inspired modernity - that a new paradigm is likely to arise in Dussel's view. Taking that the premodern must re-emerge for ethical, political, ecological and cultural reasons, this paper sticks to Sardar's standpoint whereby the transmodern must constitute a reconfiguration of the conception of tradition to build up new spaces for relationality. Indeed, the collision between the paradigms of Western and Muslim countries comes from the misinterpretation (if not contempt) of Muslim tradition as retrograde and its replacement with modernity and postmodernity; the West, Sardar points out, "has always seen Islam through the lens of modernity and concluded that it is a negative, closed system" (2004: n. pag.). In brief, Muslim countries were deprived of their 'essence' and the vacuum was forcefully filled with Western modernity premises that clearly scorned that very essence. For Sardar, the transmodern can revert this process of discord and subjugation:

Transmodernism goes beyond modernity; it transcends modernity in that it takes us trans i.e. through modernity into another state of being. Thus, unlike postmodernism, transmodernism is not a linear projection. We can best understand it with the aid of chaos theory. In all complex systems - societies, civilisations, eco-systems etc. - many independent variables are interacting with each other in great many ways. Chaos theory teaches us that complex systems have the ability to create order out of chaos. This happens at a balancing point, called the 'edge of chaos'. At the edge of chaos, the system is in a kind of suspended animation between stability and total dissolution into chaos. At this point, almost any factor can push the system into one or other direction. However, complex systems at the edge of chaos have the ability to spontaneously self-organise themselves into a higher order; in

4 Also J. Carles Lainez does so (2013: 161-172). 
other words the system 'evolves' spontaneously into a new mode of existence. Transmodernism is the transfer of modernity from the edge of chaos into a new order of society. As such, transmodernism and tradition are not two opposing worldviews but a new synthesis of both. (2004: n. pag.)

Sardar echoes and updates Dussel's 'jungle', as well as the metaphor of the rhizome, making reference to a new social ecology. In rejecting linearity, Sardar is rejecting (or rather revising) modernity and somehow claiming a rhizomatic relation between the West and the East. In retrieving 'chaos theory', he is turning science against itself, at least in its traditional fashion. In fact, it could be argued that what Sardar calls 'edge of chaos' is akin to the paradigm shift transmodernism entails. Imitating the way nature or the human body regenerate after a crisis, complex systems evolve into higher orders of existence. The poetic iconography in Malick's The Tree of Life (criticised for its alleged Christian undertones) testifies to this process. Drawing on Sardar, texts like Malick's accommodate and re-evaluate tradition instead of considering it a threat. This revival of tradition implies coming back to humanness and nature as the reserves of one another; trans-formative and transcendental in their own way. The Tree of Life addresses this return to origins or rather the origin of the planet itself - for the main character, Jack, to come to terms with himself and what it involves being a human. Jack recalls his childhood and early youth subsequent to his brother's death. This dramatic episode triggers the protagonist's flashbacks and existential questions, mostly voiced by a thirdperson narrator. The film conjures up the primordial through a stellar imagery which echoes Kubrick's 2001: A Space Odyssey (1968). Yet, instead of Kubrick's coldness, Malick's text is informed by a poetics of empathy related to the current paradigm shift. It is no longer Kubrick's confrontation of tribes of ape-men who, inspired by a monolith, learn to fight the enemy. In its place, a dinosaur lumps into a deadly victim next to a river and decides to leave it alone out of empathy. In short, The Tree of Life not only argues for a return to nature, but to empathy as the nature of the human, much in line with Rifkin's belief that "we are a fundamentally empathic species" (2009: 1) and Sardar's transmodern (re)conciliation. Jack recalls the tree in front of his childhood home as well as the tall trees he looks at rising to the sky. As in Dussel's 'jungle', the forest constitutes the actual reserve and redemption for the grown-up Jack, the tree being no longer arborescent and genealogical, but rhizomatic. Likewise, Sardar's transmodernism is the reserve and redemptive force for current crises at the edge of chaos.

Unlike Magda's dialectics, Sardar's synthesis is one of hopeful encounter; one which draws on Rifkin's 'global empathy' (2009) and Ghisi's planetary vision whereby "we are all (including plants and animals) connected into one system, which makes us all interdependent, vulnerable and responsible for the Earth as an indivisible living community" (qtd. in Ateljevic 2013: 203). It is in this sense 
that spirituality and tradition cannot be excluded, but considered integral to humanness. It is not, as Ateljevic argues, that religious dogmas should be rejected (Ateljevic 2013: 203) mostly out of a reductionism. Maybe it is time to really delve into the Other and understand the logic of dogma, and both transmodernism and nomadism can prove helpful in this purpose. There is obviously fundamentalism on both sides which tries to impose a set of ideas. But, as Sardar points out, Islam's intrinsic values are not to be feared, neither to be pushed in Western (post)modernity. Indeed, in a transcultural fashion, they can enrich and be enriched by the Other, the Other being the West as well. Islam concepts "include such notions as tawheed (unity), khilafah (trusteeship), ijtihad (sustained reasoning), ijma (consensus), shura (consultation) and istislah (public interest)" (Sardar 2004: n. pag.). Contrary to mainstream beliefs, the above values comply with relationality and dialogue rather than fundamentalism. In other words, these values of community, consensus and mutual interest as part of integrity with the Other (be it other humans, the planet or God) are in line with current environmentalism and the ethical respect for the Other (in Lévinas and Derrida among others) in transmodernity.

The cultural events mentioned above address this transcultural stand which aims at replacing the arborescent with a planar schema. The premodern, modern and postmodern, the Same and the Other, constitute a jungle of possibilities that resurface palimpsestuously and spread like rhizomes do. This move from 'the edge of chaos' into a new order is traceable in many cultural events. Yet, as mentioned above, this paper focuses on Hozier's “Take me to Church”, Galgut's In a Strange Room, and González Iñárritu’s Babel.

\section{The Texts}

\section{a) “Take me to Church", the Palimpsestuous Re-surfacing of the Premodern}

Of the three 'texts', Hozier's musical hit is perhaps the least obviously transmodern. However, its transculturality makes up a palimpsest, its lyrics and iconography furthering and contradicting one another. The clip follows a double narrative and temporality: the love story of the two male protagonists and the violent rally against one of them. Being shot in black and white and fast-paced, the video suggests an imminent threat and places the viewer in an empathic (rather than identificatory) position with the victim. In other words, following Dominick LaCapra, the distance between victim and witness is held at bay through 'empathic unsettlement', thus averting the over-identification on our part and 
prompting commitment with the other instead (2001: 178). At the beginning of the clip, the victim-to-be is shown digging a hole to hide a small chest. The content is never revealed. However, it is eventually the target of his homophobic persecutors; a sort of metaphoric crypt (akin to Abraham's and Torok's phantom in The Shell and the Kernel [1994: 171-176]) of his non-normative sexuality, a foreign body in the social body they aim to expunge. Before the rally, the video features the two main characters kissing each other in an idyllic scenario. Yet, danger is never too far from Arcadia. Love scenes are brief and soon interrupted by images of terror and violence. A screen showing a homophobic manifestation in Russia frames the loving scenes, averting the thin line between homosexuality and homophobia via homosociality. In other words, Sedgwick's homosocial continuum $(1985,1991)$ shapes the homophobic iconography of Hozier's video. A gang of skinheads makes their way towards their victim. The sense of vulnerability is achieved by having the young gay's house isolated, which thus becomes an easy target for his aggressors. Indeed, the images of the two boys kissing are interspersed with the violent raid of the skinheads blockading the house. Along most of the video, the camera moves after the protagonist's lover, who desperately looks for his boyfriend only to eventually witness the assault. The Ku-KluxKlan-inspired iconography of the homophobes and their quasi-military movements foreshadow the worst omens. They find their victim's small chest, a proof of his dissidence, secrecy and otherness. And thus starts the macabre festival. Dragging the youth and setting fire to everything related to him, they re-enact the 'poetics' of the Holocaust. The clip closes with one of the protagonists watching his boyfriend's ritualised sacrifice, the aggressors trying to open the chest (a symbolic rape of his sexuality) and kicking him while he lies on the ground next to the sacrificial fire.

Hozier's clip addresses the palimpsestuous expression of homosexualityhomosociality-homophobia, its points of intensity being the links between these concepts and their transcultural re-presentation and manipulation by Power's homophobic discourse: the homosocial surface is often palimpsestuously interspersed with homosexual and homophobic signs. In other words, drawing on Sedgwick, the text focuses on gay exclusion as a widespread event against the backcloth of normative homosociality and homophobia. "Take me to Church" is not motile in the classical sense. That is, the characters and action do not travel or shift. However, the camera moves and takes viewers transculturally from Catholic Ireland to Putin's Russia. And thus it puts forward the clash between the palimpsest - i.e. the West, as apparently civilised and inclusive (i.e. homo-friendly) and the palimpsestuous signs that emerge -i.e. the East (or 'elsewhere'), as violent and homophobe. For many, the song has become "a protest song against gay discrimination in Russia” ("Hozier's Song Against Gay Discrimination in Russia 
Top Spotify Single"); a new reaction of the West to Putin's law banning gay propaganda among minors. The gap between the West and the Other is biased, though. In fact, Christian leadership has traditionally supported homosociality, furthered homophobia and condemned homosexuality as a deviation children must be protected from. This is rather paradoxical when cases of paedophilia among Catholic priests multiply worldwide. Homophobic hatred is as multiple, connective and decalcomaniac as a rhizome, the nemesis of a rhizome indeed. Its branches traverse and link transculturally, making the here and there analogous and thus rejecting the easy clash West-Other. The screening of Russian neo-Nazis is akin to the gay assault in Ireland, which is akin to the Catholic-inspired litany of the lyrics. Hozier's song is the plateau: transcultural, image, text, music that dismantles the homosocial.

As a transmodern text, "Take me to Church" rejects the alleged moral superiority of the West. It is true, though, that whereas Putin's execrable policy has been censored, the even more violent homophobia of other (particularly African and Arabic) countries has not met the same response. Once again, it seems to me, the East/West divide prevails, taking Russia as the legitimate Other, while institutional and practical homophobia in Africa and some Arabic countries is taken as a logical consequence of their alleged underdevelopment. With this I do not mean Hozier's disapproval of Russian homophobia and the rise of extreme right parties and movements in Europe is negligible or that homophobia in Africa and Arabic countries is not loathsome. On the contrary, transmodern art manifestations address the transcultural dimension and relatedness of most phenomena, a renewed sense of hatred and segregation unfortunately being one of them. Parallel to unprecedented solidarity and tolerance, as the love relationship of "Take me to Church" proves, there is an increasing sense of dispossession, vulnerability and exclusion transmodern texts reflect and try to combat.

The sense of crisis, as well as the actual crisis, make up a scenario where the conflict East/West is projected onto a domestic level, making good transmodern glocality. The glocal is, in fact, the plateau where the global and local coalesce. The microfissures between the lyrics and the imagery in Hozier's song make up the palimpsest the song constitutes: connective, denouncing hatred and addressing clear signs of conscience raising and empathy.

"Take me to Church" transcends (Russian) homophobia, drawing on a certain idea of glocal Irishness, one that reappraises its spirituality as a trace of what Lainez (2013: 168) calls the forgotten premodernity. Conversely, the video transcends Irish Catholicism using its contradictions against itself and to censor hatred worldwide. It is in this sense that Sardar's quantum leap between tradition and its revision to gain order on the edge of chaos is especially meaningful. Photographer and music director David LaChapelle and ballet dancer Sergei 
Polunin presented a video cover on Hozier's song (2015), which constitutes an allegory on (gay) human's vulnerability, a call to spiritual rebirth and ultimately a palimpsest on Hozier's original. Ukrainian-born Polunin is trapped in an uncanny space, a sort of church-like structure whose walls and windows have been removed. From a bare body on the floor, he starts a frenzied dance within the building. The emasculating atmosphere and physical limits he is confined to are released when light comes through and floods the scenario. The epiphanic encounter with a life-giving light coming from above has obvious religious connotations as well as one of homo-social/sexual healing. The excluded is thus granted a new nature and social role, albeit still precarious, via transcendence.

Sardar relies on transmodernism to update Islamic tradition. Likewise, "Take me to Church" returns to Christian ethics as a premodern discourse to build up a new spirituality. In the era of exclusion, when Europe has proved unable to implement a common policy with regard to refugees, and confrontation and suspicion of the Other is widespread, Hozier's text opts for a relational ethics which makes the palimpsest a metaphor of political action. It seems to me that the core problem the text poses is analogous to the one Sardar points out in relation to Muslim countries. Transmodernism may be a response to Western desacralisation (Lainez 2013: 161) in the way it can be to Muslim tradition. In other words, modernity and postmodernity not only repressed Muslim tradition. Western premodernity (Christ's actual message as transgression) was also expunged as retrograde, irrational and contrary to progress. Hence, Western suppressed tradition is akin to Dussel's 'jungle'; that is, a space which, unlike current neoliberalism, calls for a return to pre-modern (human) nature and is thus full of possibilities to address current crises. "Take me to Church" is thus not against religion. It confronts religion against itself to come to terms with spirituality and the sacred, mostly by reconciling humans with humanness. This it does by merging messages, iconography and lyrics, what is seen (gay love and gay hatred) and what is suggested (the homosocial system that supports this dichotomy), as palimpsestuous palimpsests do when arising through the microfissures of the surface text.

Drawing on the transmodern return to the premodern (Dussel, Sardar and Lainez), Gilles Lipovetsky contends that new ways of experimenting spirituality coexist with (and increasingly supersede) conventional religion (2004: 62). In an interview, Hozier joins them all, displacing sacredness and spirituality from religious hierarchy to other manifestations of spirituality:

I would love to get in trouble with the Catholic Church. I'm not religious myself, but my issue is with the organisation. It's an organisation of men-it's not about faith. I don't want the song to be considered an attack against faith, but when you have people feeling ashamed of themselves because of sexual orientation, or put themselves at risk by people telling them 
what [not] to put on the end of their penis, well, you wouldn't tolerate that from a company, or a government. (Hozier 2015: n. pag.)

The lyrics are rather misleading because they recurrently talk to a 'she' who remains a mystery throughout. Who is this Goddess who, rumour has it, "giggles at the funeral", despite knowing "everybody's disapproval" (Hozier 2014: "Take me to Church")? Why does the lyrical voice regret not having worshipped her before? The song is cryptic and poses more questions than it answers. The girl laughing echoes the Goddesses repressed by what Riane Eisler (1988: xvii-xviii) calls the male blade or the domination model. In this sense, "Take me to Church" reappraises the alternative partnership model and pre-Christian worship of nature, a sheer substratum of Irish Catholicism, as well as of modernism and postmodernism in Latin America. The lyrics feature the transition from the premodern partnership model to the domination one, from the Mother to the Father, from the chalice to the blade, and backwards. This is the motility, so to speak, furthered by the video and lyrics, a sense of 'transness' that is geographic, historical, cultural and ideological. The lyrical voice proclaims itself "a pagan of the good times" and its beloved is "the last true mouthpiece" and "the sunlight" (Hozier 2014: "Take me to Church"). The (Irish) pagan substratum proves to be 'the truth', which the lyrics link to pre-Christian idols like Mother Earth and the Sun. Despite the linkage between pagan and orthodox cults, "Take me to Church" stages the traumatic change of station when the official church took control and repressed non-Christian rites and beliefs. Every Sunday, the song says, "it gets more bleak" as "fresh poison" is added (Hozier 2014: "Take me to Church"). In other words, Catholic hierarchy stifles its followers, particularly the excluded: "We were born sick, you hear them say" (Hozier 2014: "Take me to Church"). And here comes the core of Hozier's musical text: Christianity paradoxically goes against Christ's ethics of alterity when sexual dissidents are equally excluded by neo-Nazi groups, their state-sponsors and Catholic hierarchy. A politics of inclusion of the subaltern is thus mandatory instead, updating a spirituality that, the song claims, has no absolutes.

The countercultural discourse of "Take me to Church" is patent as it re-appropriates sickness and sin, thus breaking the fragile equilibrium between homosociality, homosexuality and homophobia. The lyrical voice loves being sick. And he boasts about being a sinner, although (or because) he triggers his aggressors' rage: "I'll tell you my sins and you can sharpen your knives" (Hozier 2014: “Take me to Church"). The re-appropriation of homophobic attacks has a religious and political goal. He offers himself in sacrifice to his aggressors' knives while his Goddess demands for a sacrifice as well. In this way, not only does he challenge homophobes. Sacrifice itself becomes an act of political and sexual dissidence, and one 
of renewal. Indeed, in deconstructing the logic of the sacrificial offering and conferring it a sexual dimension, "Take me to Church" points to a palimpsestuous sense of spirituality, premodern and transmodern at the same time.

\section{b) In a Strange Room, the Transmodern Rhizome in Motion}

Shortlisted for the 2010 Booker Prize, Galgut's novel is paradigmatic of the motile globalised transmodern text. If "Take me to Church" is mostly a palimpsestuous text addressing global interconnectedness bi-dimensionally, In a Strange Room updates the 'trans-plicity' of the rhizome. The novel is split into three parts connected by the main character and narrator. A young South-African man by the name of Damon, Galgut's first name, keeps travelling and morphing from "The Follower" of the first section to "The Lover" of the second to "The Guardian" of the third. This sense of 'transness' also applies to the narration, which changes intermittently from the first to the third person and back, swinging between memoir and fiction, and thus testifying to the transcultural hybridity of the novel. Nothing about In a Strange Room is new, but the assemblage it constitutes. Travel literature is a classic genre, and experimentalism in narration and focalisation techniques was started by modernism and popularised by postmodernism. However, the sense of globality and the way the novel addresses Otherness (be it nature, people, emotions) from the perspective of the other are neatly transmodern. Damon is SouthAfrican and his platenarist worldview is austral, having the traditional North-South (and West-East) axis displaced. Although the protagonist travels firstly to Greece, across Africa and to Europe and India later, Southern Africa remains the 'centre' of his rhizomatic, de-centred discourse and geography. Indeed, Damon always returns to Africa, where humankind started. Specifically, he lives next to 'The cradle of Humankind', the paleoanthropological complex in Johannesburg; hence, the primordial character of the novel's planetarism. In travelling through Africa, Damon says: "The rhythms of daily life are dictated by the larger ones of nature, the sun or moon for example, something has lasted here from the mythical place before history set itself in motion" (Galgut 2010: 79, my emphasis). However, the first story sets off in Mycenae, the cradle of European culture. Despite being set in primal sites, In a Strange Room is not genealogical. These are myths of origin with a symbolic meaning that traverses and connects different cultures in a transmodern context. Drawing on Dussel's 'jungle', these mythic sites are reservations of humankind for it to come to terms with itself. Mycenae, Johannesburg, Goa, past and present, constitute sites of memory that travel into each other. Likewise, Damon's encounter with the German traveller Reiner turns into a 'site' that comes back in the form of memory stills (Galgut 2010: 10). 
Reiner is Apollonian, "his body [...] brown and hard, perfectly proportioned" (Galgut 2010: 4) and a bisexual (Galgut 2010: 11). For unknown reasons, Damon decides to follow him in Mycenae; hence the title of the section. From Mycenae to Sparta, from there to Pylos, they move around the country. However, the overall impression the narrator suggests is one of rhizomatic deterritorialisation and even of dissociation. Damon is a spectator of himself. Moreover, what happens "is happening in two places, at another point on the planet and at the same time on the television set. [...] Too much travelling and placelessness have put him outside everything, so that history happens elsewhere, it has nothing to do with him" (Galgut 2010: 14). Damon's experiences and how he goes through them constitute the novel's plateaus, where fragments, sediments of multiple others' experiences converge across the microfissures of his/their discourse. Damon and Reiner are nomads rejecting a place to live. Yet, unlike migrants, mostly moved by scarcity, fear and/or hunger, Damon's nomadism is fuelled by grief (Galgut 2010: 14), which is particularly poetic. Back in South Africa, he is visited by Reiner and their travel together continues through Botswana, Namibia, Zimbabwe and Lesotho. Time and space follow the same rhizomatic pattern since they are one and the same thing. The past, the narrator argues, "echoes in concentric rings through time" (Galgut 2010: 23). Likewise, space follows a pattern that blends with that of the protagonist: "He is attuned to the rhythms of the universe, the rhythms of walking no different to those of living” (Galgut 2010: 32). The connection between Damon and the African landscape is particularly complex as it follows the concentric pattern of time when he and Reiner walk the wide space: "They are walking in a big circle [...] from where they will begin a second and larger circle, ending in almost the same place, from where they will begin a third. In this way they will traverse the country in three growing loops" (Galgut 2010: 33-34), thus making up a plateau. Indeed, a plateau is a circle or convergence that "can be read starting anywhere and [...] related to any other plateau" (Deleuze and Guattari 2015: 22). In this sense, the circle formed by both men and the land they walk is rhizomatic: their motion is multiple and relational, materialising in a cartography of lines of flight whose intensities coincide with the circles/loops they make up. In parting with Reiner, the loop breaks away and so does Damon's “ability to love people or places or things" (Galgut 2010: 71). However, intensities recur throughout the novel. No matter how multiple and fragmented reality is, there are plateaus where the loops made up by different human experiences connect: "In this place each of them is at the centre of the universe, and at the same time is nowhere, surely this is what it means to be spiritually fulfilled, they are having a religious experience" (Galgut 2010: 79).

When Damon meets three Swiss travellers, he falls for one of them, Jerome, who "has from up close a beauty that is almost shocking" (Galgut 2010: 77). There- 
after, the protagonist cannot help following Jerome on his way across Africa: Zimbabwe, Malawi, Tanzania, Zanzibar, Kenya ... . Echoing the way Damon had been led by Reiner in the first section, his pilgrimage after Jerome puts forward again his connectedness with the other, which turns a synecdochical link with planetary rhythms:

The world you're moving through flows into another one inside, nothing stays divided any more, this stands for that, weather for mood, landscape for feeling, for every object there is a corresponding inner gesture, everything turns into metaphor. The border is a line on a map, but also drawn inside himself somewhere. (Galgut 2010: 91)

The planar, horizontal relationality of the rhizome is once more confirmed by the protagonist's discourse. As inside (his body's circadian rhythms) so outside (the world's own motility) and vice versa, and thus, the concentric circles and loops in which Damon and Reiner orbit recur in this new episode of linkage with the Other. Paradoxically though, the novel's sense of movement always ends in failure. Moving is no warrantee of definite bonds between characters, but rather of characters' becomings. Indeed, Damon's moving, which is connected to the others' motility, is an end in itself. The emphasis is not on goals, but on processes, often meaningless even for the protagonist himself. He crosses borders with no apparent objectives and, when there is one - e.g. he feels attracted by Jerome - it rapidly fades away. Since Jerome is an obsession, an illusion or a metaphor of his desire, Damon eventually returns home in the full sense of the term: "He can't go back to the way he was living before, the endless moving around, the rootlessness. So the idea of [a] house [...] is like a fresh beginning, the possibility of home" (Galgut 2010: 129). This is the moment of major intensity, when the microfissures between himself and his surroundings are wide open: "A sort of intimacy develops between him and the place [...] when old dead branches begin to sprout buds and leaves [...] he feels as if it's happening inside himself" (Galgut 2010: 130). Yet, the rhizome that governs Damon's existence is far more complex than the rootlessness he mentions and thus his travelling goes on.

The third section constitutes the third loop, the third concentric circle in Damon's pilgrimage. This time he travels to Goa as a chaperon to his maniacdepressive friend Anna; hence the title, "The Guardian". As with his previous travelling, their "big looping journey [...] is just one more complicated circle, bringing them to exactly the same point" (Galgut 2010: 154). The point of intensity is somehow displaced and controlled by Anna's disarray. For the first time in the novel it seems 'the edge of chaos' is not going to be replaced by a higher order: "It's as if her chaos has leaked out somehow and touched the physical world, throwing people and objects into disarray" (Galgut 2010: 149). Their rhizomatic order (for there is order in the rhizome) is out of control when she attempts to commit suicide. 
Thus starts Damon's frenetic journey through Goa to save her and indirectly himself. "I'm not doing it for you" he tells Anna “I'm doing it for other people who love you. And for me, so that I can look myself in the eye" (Galgut 2010: 176). The sense of multiplicity and connectedness towards the Other characteristic of the transmodern text holds until the very end. In leaving Goa, he notices that Anna's story "travels into him [because] his skin is very thin, there's no barrier between him and the world" (Galgut 2010: 188). Damon's liminal status is linked to his rhizomatic sense of memory. He confesses that what he lived through "will recur in an almost cellular way, haunting him" (Galgut 2010: 188). Memory, as recalled lived experience, works as cells and rhizomatic nods do, rejecting and assuming a chaotic order based on multiplicity and connectedness. These features draw on dendrites and axons, the branches, middle areas of neurons, which form "a dense meshwork of meta-stable connections rather than a stable, centered tree-structure" (Holland 2013: 41). In a Strange Room is made up of these non-places where characters and events coalesce. Damon feels attached to the Other, not out of an over-empathic unsettlement, as pointed out before, but because he is the Other. This explains how his memory traverses time, but also how his physicality mutes and connects like cells do. That is why he is affected by "the news of an earthquake on the other side of the world" (Galgut 2010: 192), his (and the novel's) conception of life being planar and relational. Hence, when he inexplicably weeps while leaving Goa, he comes back to himself and concludes: "Lives leak into each other, the past lays claim to the present” (Galgut 2010: 193). Life flows unexpectedly through microfissures and In a Strange Room is made and traversed by them.

\section{c) Babel, or Transmodern (Mis)communication}

González's Iñárritu's film Babel is also made of microfissures that connect different stories into a presumably integrated whole. Most reviews consider it an ambitious, conceited film (Scott 2006: n. pag.; Bradshaw 2007: n. pag.). Besides, Scott argues that it "belongs to an increasingly common, as yet unnamed genre 'Crash' is perhaps the most prominent recent example - in which drama is created by the juxtaposition of distinct stories, rather than by the progress of a single narrative arc" (2006: n. pag.). In my view, juxtaposition in Babel is characteristically transmodern and, more concretely, trans-cultural/national. As a transnational event in the era of 'world cinema', ${ }^{5}$ the film breaks with older concepts,

5 The label "world cinema" has been a much-debated and contested one in the last two decades. For further information, see Hill and Church-Gibson (2000) and Nowell-Smith (2000). 
particularly nation-states, and is defined instead by globalisation as the new Grand Narrative, in Magda's words. Yet, in Deborah Shaw's view, Babel cannot be simply labelled as world or globalised cinema (Zaniello 2007: 16), but as a hybrid (Shaw 2011: 13) because it "attempts to create a 'world cinema' gaze within a commercial Hollywood framework" (Shaw 2011: 11). From this initial hypothesis, Shaw wonders to what extent the film is a conservative text that complies with Hollywood's 'tourist gaze' or, on the contrary, whether it is a 'genuine' world text that transcends Western premises. In a rather pessimistic vein, she concludes that Babel lacks "a political vision that explores the ways in which U.S. power structures are played out in specific political contexts" (Shaw 2011: 28). It is true that American characters' views prevail and the Americans are eventually saved while Mexicans and Moroccans are doomed. In that sense, Gonzalez's film both deconstructs and relies on the tourist gaze, being a Hollywood product that aims at a worldwide authorship/spectatorship. However, I do not think it is a conservative text or a flawed one because it lacks cultural and national roots (Shaw 2011: 28). As will be shown above, although Babel is a Western product, it attempts to replace cultural and national roots with metaphoric links that connect and are connected transculturally and transnationally.

The episode of Babel takes place in the eleventh chapter of Genesis. Being so conceited as to build up a tower to heaven, humanity is punished with dispersal and misunderstanding. Indeed, biblical miscommunication is the underlying message from the first scene of the film, when a butterfly flaps wings. The image is obviously linked to the so-called butterfly effect, whereby "an insect fluttering its wings in the Amazon Basin can initiate a chain of events that ends in a hurricane in the Indian Ocean" (French 2007: n. pag.). Like In a Strange Room and The Tree of Life and, to a more limited extent, "Take me to Church", Babel is a planetarist tale about human ecology, especially the interweaving events that make up globality. Characters are hopelessly trapped in a precarious relatedness. However, underlying failure, misunderstanding and hatred - a hunting rifle being the connecting item of all the plotlines - there are still acts of love and empathy that, like Dussel's 'jungle', can redeem humankind.

The film is set in four different places, Morocco, California, Mexico and Japan, thus continuing the transmodern motility of In a Strange Room. And, as happens with the butterfly flapping, an accidental event in a remote desert in Morocco has unexpected effects in other parts of the planet. A shepherd buys from a neighbour a hunting rifle which he hands out to his young sons, Yussef and Ahmed, to keep away the jackals from the herd. The two boys are shooting when one of the bullets accidentally reaches an American woman, Susan Jones (performed by Cate Blanchett) on holidays with her husband Richard (Brad Pitt). Thus begins the couple's odyssey in the bare hills of the Moroccan desert. At the same time Amelia, the 
Mexican housekeeper of two North-American children, decides to take them to Mexico (unable to place them with any of her colleagues) to attend her son's wedding. What starts as a family celebration ends in another odyssey. Back from the wedding, Amelia and her nephew Santiago are stopped by US border officers who suspect they have kidnapped the two children. It is then that Santiago starts his car driving into the desert. He leaves his aunt and the children behind so as not to be deported, which is what happens to Amelia when the police finds the children she has left in the desert to seek for help. Only at the end do we learn the American tourists in Morocco are the children's parents. The third plot turns around Chieko, a deaf Japanese girl, who has recently lost her mother. Her awakening to sexuality is marked by her mother's death, her disability and boys' response to it. Restrained but emotional, Chieko's story firstly seems disconnected from the rest of the film. However, when a couple of policemen want to talk to the girl's father, the circle is closed. A keen hunter, Chieko's father gave a shepherd a hunting rifle in thanks to his services while in Morocco. This is the rifle the two Moroccan youngsters played with when a bullet astray reached the American tourist.

The transmodern in Babel is not only transcultural, but also translinguistic. The film is spoken in English, Spanish, Arabic, Berber, Japanese and sign language. Thus, the hardships of communication refer back to the Biblical reference of the film. Some critics have already addressed its poetics of incommunication (Fernández et al. 2004; Solé and Valero 2010) and of confusion (Bert Olivier 2009). However, I contend that humankind's heteroglossia (as failure rather than mutual enrichment) is offset through deterritorialisation and points of intensity. Babel is mostly set in deserts, in Morocco, the US-Mexico border and Tokyo. Deserts are sites of bare life because life there is vulnerable to solitude, emptiness, police forces or an indifferent crowd respectively. However, these scenarios are deterritorialised when microfissures open to one another in the form of television images or photographs. The events taking place in these scenarios cross the Earth as wormholes allegedly do in the universe. The existence of wormholes is still an unproven theory but a valuable metaphor to render the quasi-magical relationality of peoples and events across the planet and in different moments as represented in texts. Time and space are thus reduced to one dimensionality the characters of Babel unconsciously share. It is as if the text (like the Earth or the Universe) folded within itself and hence inner channels of communication and relationality opened as a result. It is not only that, as Fernández et al. argue, scenes of the film are related symbolically as hyperlinks do: whereas in the Moroccan subplot the two brothers hide when one of them shoots the American tourist, the American children play hide and seek with Amelia; likewise, at the end of the film, when both the Moroccan children are about to be shot by soldiers 
and the American ones are about to be rescued by the police, they all are pushed by the wind (Fernández et al. 2004: 6-7). It is also that the web, the screen and other media constitute the actual vehicle of these links. Yet, these connections transcend technology and address affects and ideology as well. When Chieko changes television channels, images from the American couple in Morocco go through the screen transformed by the medium: the accident is no longer an accident, but a terrorist attack broadcast worldwide. Likewise, at the end of the film, one of the police officers going after Chieko's father watches the images of the American couple happy after agony on the screen. There is a proliferation of television images that traverse ontological walls rhizomatically, not only turning an accident into terrorism, but into a metanarrative of apocalyptic films where (Western) families survive. In Morocco, when the shepherd is mistreated by the police because he owns the rifle of the crime, he shows a photograph of himself with Chieko's father after hunting to prove his innocence. Simultaneously, in Tokyo, Chieko shows a copy of the same photograph to the police. Like television images, the still is a wormhole that transforms and becomes reality. The shepherd is not the terrorist authorities suspect, but a poor man who was given a rifle in thanks. Chieko's father is not the criminal one could suspect, although the police is after him. The camera travels after the stories and their protagonists, transforming so-called reality and deterritorialising scenarios in a transcultural narrative.

Despite the film's overall sense of miscommunication, there are some intensities that join characters together in a rhizomatic fashion. In other words, affects resist against all odds in unexpected ways in the middle of ill-fated characters and plot lines. Human ecology and Dussel's 'jungle' blend into love as society's redeeming feature. Transmodern integration of the common within the different is mostly a question of empathy and love. When the Moroccan police officers shoot Yussef dead, Ahmed blames himself and turns himself in to his brother's murderers confessing he shot the tourist. It is an act of bravery from a 12-year-old boy, but especially of love for the other in a desert of affects. Likewise, Richard and Susan, who are trying to overcome the death of their infant child, prove their unconditional love for each other when facing death together. Also, Amelia proves empathic to the gringos who eventually deport her. She risks her life in the desert to save the Jones's children only to be made responsible for their loss. Yet, her love for them is unflinching. This is the lesson of transcultural interaction and transmodern communion. The human ecosystem featured in Babel, like Dussel's 'jungle', is a response to current concerns and possibilities humans encounter in meeting the other: when communication is easier, there is more solitude than ever; when travelling is frequent, remoteness gains meaning, when technology threatens with dehumanization, humanness and empathy become vital. 


\section{Some Concluding Remarks}

Transmodernism has so far not been so far addressed in English studies, but in Iberian and Latin-American circles. ${ }^{6}$ This article constitutes a first attempt to explore its possibilities within the field. Transmodern texts share a transcultural dimension traceable in their motility and nomadism, but also in their fragmentariness and their rhizomatic multiplicity. All in all, "Take me to Church", In a Strange Room and Babel contemporise and galvanise the lines of flight they convey. Through a number of metaphors that draw on narrative (the palimpsestuous palimpsest), philosophy (rhizome), and social ecology (the jungle), texts prove to be transmodern reservations that make difference converge. It is not equality and sameness which are aimed at, but common territories, points of intensity, Deleuze and Guattari's plateaus. Indeed, the tropes of Deleuze and Guattari, Dillon and Dussel attain material, political and ethical undertones.

Whether transmodernism is a fact to be detected and analysed, as Rodríguez Magda suggests, or a process of becoming, as Ghisi and Sardar argue, it is a complex paradigm. The texts are a priori failed attempts to communicate. Hozier's homophobia proves a short-circuit between homosociality and homosexuality. The nomadism of Galgut's protagonist seems pointless, a failure to follow, love or guard the other. G. Iñárritu's film bends on itself, opening microfissures that connect characters. However, they seem unable to hear and/or understand each other. There is room for hope, it seems to me, though. No matter how flawed connectedness within these texts is, 'transness' is essentially relational. Indeed, all these texts argue for empathy, even when empathy itself is ambivalent.

\section{Works Cited}

Abraham, Nicolas and Maria Torok. 1994. The Shell and the Kernel: Renewals of Psychoanalysis. Ed., trans. and with an Introduction by Nicholas T. Rand. Chicago, IL: Chicago University Press.

Ascari, Maurizio. 2011. Literature of the Global Age: A Critical Study of Transcultural Narratives. Jefferson, NC: McFarland.

Ateljevic, Irena. 2013. "Visions of Transmodernity: A New Renaissance of our Human History?" Integral Review 9.2: 200-219.

Babel. 2006. Dir. Alejandro Gonzalez Iñárritu. Paramount Pictures. DVD.

6 The fact that Transmodernity: Journal of Peripheral Cultural Production of the Luso-Hispanic World is virtually the only journal devoted to transmodernism is very significant. Some US-based scholars like Linda Martín Alcoff and Walter Mignolo have participated, but mostly focusing on the Latin dimension of the concept. 
Bradshaw, Peter. 2007. Review of Babel, by Alejandro Gonzalez Iñárritu. The Guardian January 19. <https://www.theguardian.com/film/2007/jan/19/drama.thriller> [accessed 25 April 2017].

Braidotti, Rosi. 2011. Nomadic Theory: The Portable Rosi Braidotti. New York: Columbia University Press.

Dagnino, Arianna. 2015. Transcultural Writers and Novels in the Age of Global Mobility. Comparative Cultural Studies. Lafayette, IN: Purdue University Press.

Deleuze, Gilles and Félix Guattari. 2009. Anti-Oedipus: Capitalism and Schizophrenia. Trans. Robert Hurley. With an Introduction by Mark Seem and a Preface by Michel Foucault. London: Penguin Classics.

Deleuze, Gilles and Félix Guattari. 2015. A Thousand Plateaus: Capitalism and Schizophrenia. Bloomsbury Revelations. London: Bloomsbury Academic.

Dillon, Sarah. 2005. “Reinscribing De Quincey’s Palimpsest: The Significance of the Palimpsest in Contemporary Literary and Cultural Studies". Textual Practice 19.3: 243-263.

Dussel, Enrique. 2002. "World-System and 'Trans'-Modernity". Nepantla: Views from the South 3.2: 221-244.

Eisler, Riane. 1988. The Chalice and the Blade: Our History, Our Future. New York: Harper One.

Fernández, Victor Garcés, Daniel Martínez Galarza, Iñaki Miedes Gónzalez, José Manuel Sánchez Torres, Ignasi Soler Torro and Laura Soriano Fortanet. 2004. “BABEL: Narrativa de la Incomunicación”. Issued by BOCC: Biblioteca Online de Ciências da Comunicação. <http://www.bocc.ubi.pt/pag/aavv-2013-02-04.pdf〉. [accessed 12 September 2017]〉.

French, Philip. 2007. Review of Babel, by Alejandro Gonzalez Iñárritu. The Guardian January 21. <https://www.theguardian.com/film/2007/jan/21/bradpitt.thriller> [accessed 25 April 2017].

Galgut, Damon. 2010. In a Strange Room. London: Atlantic Books.

Hill, John, and Pamela Church-Gibson. (eds.). 2000. World Cinema: Critical Approaches. Oxford: Oxford University Press.

Holland, Eugene. 2013. Deleuze and Guattari's A Thousand Plateaus: A Reader's Guide. London/ New York: Bloomsbury.

Hozier. 2014. "Take me to Church". Island/Columbia. Single.

Hozier. 2015. "Hozier Would Love to Get in Trouble with the Catholic Church". Interview by Lisa Robinson. Vanity Fair February 9. <http://www.vanityfair.com/culture/2015/02/hosiertake-me-to-church-grammys> [accessed 2 January 2017].

“Hozier's Song Against Gay Discrimination in Russia Top Spotify Single”. Issued by The Moscow Times, 10 December 2014. <http://www.themoscowtimes.com/news/article/hoziers-songagainst-gaydiscrimination-in-russia-top-spotify-single/513063.html [accessed 22 February 2017].

LaCapra, Dominick. 2001. Writing History, Writing Trauma. Baltimore, MD: Johns Hopkins University Press.

Lainez, J. Carles. 2013. “La Premodernidad Olvidada”. Rosa María Rodríguez Magda (ed.). La Condición Transmoderna. Anthropos 241. Barcelona: Anthropos. 161-172.

Lipovetsky, Gilles. 2004. Les Temps Hypermodernes. Paris: Grasset.

Nordin, Irene, Julie Hansen and Carmen Zamorano. 2013. Transcultural Identities in Contemporary Literature. Cross/Cultures 167. Amsterdam/New York: Rodopi.

Nowell-Smith, Geoffrey. (ed.). 2000. Oxford History of World Cinema. Oxford: Oxford University Press. 
“Palimpsest”. Issued by The Chicago School of Media Theory, 2017. <https://lucian.uchicago. edu/blogs/mediatheory/keywords/palimpsest/> [accessed 07 March 2017].

Rifkin, Jeremy. 2009. The Empathic Civilization: The Race to Global Consciousness in a World in Crisis. Los Angeles, CA: Tarcher.

Robertson, Roland. 1995. “Glocalization: Time-Space and Homogeneity-Heterogeneity”. In: Mike Featherstone, Scott Lash and Roland Robertson (eds.). Global Modernities. London: Sage. 25-44.

Rodríguez Magda, Rosa María. 1989. La sonrisa de Saturno: Hacia una teoría transmoderna. Barcelona: Anthropos.

Rodríguez Magda, Rosa María. (ed.) 2013. La Condición Transmoderna. Anthropos 241. Barcelona: Anthropos.

Sardar, Ziauddin. 2004. "Islam and the West in a Transmodern World". The Islam Online Archive August 8. <https://archive.islamonline.net/?p=14902> [accessed 17 February 2017].

Scott, A. O. 2006. “Emotion Needs No Translation”. Review of Babel, by Alejandro Gonzalez Iñárritu. The New York Times October 27. <http://www.nytimes.com/2006/10/27/movies/ 27babe.html> [accessed 25 April 2017].

Sedgwick, Eve. 1985. Between Men: English Literature and Male Homosocial Desire. New York: Columbia University Press.

Sedgwick, Eve. 1991. Epistemology of the Closet. University of California Press.

Shaw, Deborah. 2011. "Babel and the Global Hollywood Gaze". Situations: Project of the Radical Imagination 4.1: 11-30. <https://radicalimagination.institute/wp-content/uploads/2017/ 02/shaw-2011.pdf> [accessed 15 September 2017].

Stimpson, Catharine. 2016. “The Nomadic Humanities”. The Los Angeles Review of Books July 12 <https://lareviewofbooks.org/article/the-nomadic-humanities/> [accessed 27 January 2017].

The Tree of Life. 2011. Dir. Terrence Malick. Fox. DVD.

Zaniello, Tom. 2007. The Cinema of Globalization: A Guide to Films About the New Economic Order. Ithaca, NY: Cornell University Press. 